\title{
PENGEMBANGAN PERANGKAT PEMBELAJARAN IPA BERBASIS PENDEKATAN SAINTIFIK UNTUK MENUNTASKAN HASIL BELAJAR SISWA POKOK BAHASAN SISTEM GERAK MANUSIA DI SMP
}

\author{
Netty M Arumisore ${ }^{1)}$, Sifak Indana $^{2)}$, Soetjipto $^{3)}$ \\ 1) Pendidikan Sains, Pascasarjana, Universitas Negeri Surabaya \\ ${ }^{2)}$ Dosen Pendidikan Sains, Pascasarjana, Universitas Negeri Surabaya \\ ${ }^{3)}$ Dosen Pendidikan Sains, Pascasarjana, Universitas Negeri Surabaya \\ e-mail: Kezia_papua@yahoo.com
}

\begin{abstract}
Abstrak: Penelitian ini bertujuan untuk menghasilkan perangkat pembelajaran IPA yang layak untuk menuntaskan hasil belajar siswa SMP pada materi sistem gerak manusia. Pengembangan perangkat pembelajaran mengikuti model 3-D dengan ujicoba menggunakan rancangan one group pretest-posttest design. Ujicoba II dilaksanakan pada Kelas VIII SMP Negeri Rasiei Kabupaten Teluk Wondama-Papua Barat. Penelitian terdiri dari dua tahap yaitu:1) pengembangan perangkat pembelajaran meliputi RPP, bahan ajar, lembar kegiatan siswa, tes hasil belajar yang divalidasi oleh para pakar; 2) perangkat pembelajaran yang telah divalidasi tersebut kemudian diujicobakan. Instrumen yang digunakan antara lain lembar observasi keterlaksaan pembelajaran, lembar observasi kendala dalam pembelajaran, lembar observasi aktivitas siswa, dan angket respon siswa. Hasil penelitian menunjukkan bahwa: 1) validitas perangkat pembelajaran yang dikembangkan berkategori valid; 2) keterlaksanaan RPP berkategori baik; 3) aktivitas siswa menunjukan pembelajaran siswa aktif membangun pengetahuannya sendiri melalui pendekatan saintifik; 4) siswa memberikan respon positif terhadap proses pembelajaran; 5) Hasil belajar siswa baik dari aspek sikap, pengetahuan, dan keterampilan mencapai ketuntasan. Berdasarkan hasil penelitian di atas dapat disimpulkan bahwa perangkat pembelajaran IPA berbasis pendekatan saintifik pada materi sistem gerak pada manusia sudah valid, praktis dan efektif sehingga layak digunakan dalam pembelajaran dan terbukti efektif untuk menuntaskan hasil belajar siswa.
\end{abstract}

Kata Kunci: Pembelajaran berbasis pendekatan saintifik, menuntaskan hasil belajar siswa, sistem gerak pada manusia.

\begin{abstract}
The objective of this research is produce science learning tools that eligible for the completeness of learning outcome student's at subject human motion system on the junior high school. The development of this learning tools is based on 3-D model by using test based on One Group Pretest-Posttest Design. The test is conducted on eighth grade student of SMP Negeri Rasiei Teluk Wondama district-Papua Barat. The research consisted of two stages which is: 1) Developing the learning tools consisted of lesson plan, student's book, and student's worksheet, learning achievement test validated by experts. 2) the lesson learning tools which has been validated by expert is a tested. The instrumental used including observational sheet of student's activity, and student's response questionnaire. He result of the research shows that: 1) the learning tools is valid; 2) the lesson plan accoplishment is categorized as good; 3) the student's activities indicate tha they learn to actively build their own knowledge through a scientific approach; 4) the student's responded positively to the learning process; 5) the student's learning outcomes of attitude, knowledge, and skill aspects is accomplished. Based on the following results can be concluded that the science learning tools based scientific approach on human motion system is a valid, practical, and effective. Thus the science learning tools can be used on the learning process and proofed to be effective for the completeness of student's learning outcome.
\end{abstract}

Keywords: Learning Based on Scientific Approach, Completeness of Learning Outcome, Human Motion System.

\section{PENDAHULUAN}

Penerapan kurikulum 2013 menyebabkan terjadinya pergeseran paradigma pembelajaran IPA di sekolah dari paradigma teacher-oriented ke studentoriented. Peran guru bergeser dari menentukan "apa yang akan dipelajari siswa" ke "bagaimana menyediakan dan memperkaya pengalaman belajar siswa”. Pengalaman belajar IPA diperoleh melalui serangkaian kegiatan untuk mengeksplorasi lingkungan melalui interaksi aktif dengan teman, lingkungan dan narasumber lain. Pembelajaran IPA yang berpusat pada siswa dan menekankan pentingnya belajar aktif berarti mengubah pola pembelajaran guru yang selalu memberikan informasi dan sumber pengetahuan bagi siswa (National Research 
Council,1996). Berdasarkan paradigma pendidikan dalam Kurikulum 2013, pembelajaran IPA dilakukan dengan menggunakan pendekatan ilmiah yang melibatkan siswa dalam penyelidikan yang berorientasi inkuiri, dan interaksi antara siswa dengan guru dan siswa lainnya. Siswa diarahkan untuk mengembangkan kemampuan berpikir, bernalar, bekerja ilmiah melalui pembelajaran inkuiri dan pengalaman belajar (Kemdikbud, 2013).

Pengalaman yang paling tinggi nilainya adalah pengalaman yang diperoleh dari hasil kontak langsung dengan lingkungan, objek, binatang, manusia dan sebagainya, dengan cara melakukan perbuatan langsung (Zubaidah, 2013). Verbal simbol yang diperoleh melalui penuturan dengan kata-kata merupakan pengalaman belajar yang paling rendah tingkatannya. Oleh karena itu, agar pembelajaran dapat memberikan pengalaman yang lebih berarti bagi siswa, maka perlu dirancang model atau pendekatan dalam pembelajaran yang dapat membawa siswa kepada pengalaman yang lebih konkrit.

Permendikbud Nomor 71 Tahun 2013 menerangkan bahwa Pemerintah telah mengembangkan buku guru yang merupakan pedoman bagi guru dalam melaksanakan pembelajaran serta buku siswa yang merupakan buku atau sumber belajar bagi siswa. Namun menurut analisis yang dilakukan peneliti, buku guru dan buku siswa yang lelah dikembangkan belum sesuai dengan yang diharapkan karena tidak mempertimbangkan kondisi sekolah dan karakteristik siswa masing-masing daerah, terutama yang berkaitan dengan kegiatan pembelajaran. Penggunaan model dan pendekaan dalam pembelajaran masih bersifat umum karena dianggap sama kondisi sekolah, karakteristik dan tingkat pengetahuan siswa di setiap daerah. Berdasarkan hasil analisis tersebut maka peneliti merasa perlu untuk mengembangkan perangkat pembelajaran berbasis pendekatan saintifik yang disesuaikan dengan kondisi sekolah, karakterisitik siswa, serta tingkat pengetahuan siswa.

Hasil observasi dan wawancara yang dilakukan peneliti pada SMP Negeri Rasiei Kabupaten Teluk Wondama-Papua Barat, diketahui bahwa dalam proses pembelajaran IPA belum didukung oleh perangkat yang memadai sehinga siswa kurang aktif dalam mengikuti pembelajaran, meskipun beberapa guru sudah mulai berbenah dengan melakukan upaya perbaikan seperti menyajikan materi pembelajaran dengan menggunakan power point untuk menarik perhatian siswa, menggunakan media seperti charta, torso dan beberapa model pendukung, akan tetapi pembelajaran masih didominasi oleh guru, siswa masih terlihat lebih banyak duduk mendengarkan guru, mencatat dan mengerjakan soal latihan. Proses pembelajaran belum memberikan akses bagi siswa untuk berkembang secara mandiri baik dalam hal memperoleh pengetahuan, keterampilan maupun sikap. Siswa memperoleh pengetahuan dari membaca, mendengarkan penjelasan guru dan sedikit interaksi dengan benda-benda atau lingkungan yang ada di sekitarnya, akibatnya siswa menjadi pasif dan pengetahuan yang diperoleh hanya sebatas apa yang ada dalam buku teks atau hanya informasi yang diperoleh dari guru saja.

Kondisi pembelajaran seperti yang digambarkan di atas menyebabkan rendahnya hasil belajar siswa yang dibuktikan dengan rendahnya persentase ketuntasan hasil belajar siswa Kelas VIII Tahun pelajaran 2015/2016 pada semester gasal. Ketuntasan hasil belajar siswa Kelas VIII Tahun pelajaran 2015/2016 pada semester gasal SMP Negeri Rasiei Kabupaten Teluk Wondama-Provinsi Papua Barat pada mata pelajaran IPA hanya mencapai $41 \%$ sedangkan 59\% siswa dinyatakan tidak tuntas. Hasil wawancara dari beberapa siswa Kelas VIII, menunjukkan bahwa mata pelajaran IPA kurang menarik bagi para siswa. Pembelajaran IPA menjadi membosankan dikarenakan guru hanya memberi informasi kepada siswa dan kemudian memberikan beban kepada siswa dengan hafalan materi yang sangat banyak. Hal ini mengakibatkan kurangnya partisipasi dalam proses pembelajaran yang dapat mengakibatkan siswa lebih mengutamakan kemampuan menghafal dan mengingat sehingga hasil belajar kurang optimal. Zaini (2008) menjelaskan kemampuan mengingat dengan menemukan konsepnya sendiri bertahan lebih lama dari pada mendengarkan dari orang lain. Kemampuan menghafal menyebabkan siswa kurang bisa mengaplikasikan ilmu yang diperoleh di sekolah dalam kehidupan nyata, dan pemecahan masalah (Sugiarto, 2004). Oleh karena itu untuk memaksimalkan daya serap siswa dalam menerima pelajaran dibutuhkan cara belajar yang melibatkan interaksi siswa secara langsung. Dengan demikian upaya yang dapat dilakukan oleh guru agar siswa terlibat aktif dalam kegiatan pembelajaran salah satunya adalah menerapkan pembelajaran berbasis pendekatan saintifik.

Pendekatan saintifik dipilih karena pembelajaran dengan menggunakan pendekatan saintifik membuat pengetahuan yang diperoleh siswa dapat bertahan lama dan mudah diingat, dapat meningkatkan penalaran siswa dan kemampuan untuk berpikir bebas. Penerapan pendekatan saintifik khususnya pada pelajaran IPA akan memberikan pengalaman belajar yang seutuhnya bagi siswa. Penerapan pendekatan saintifik memungkinkan siswa untuk lebih aktif lagi dalam proses belajar mengajar karena pendekatan saintifik ini berpusat pada siswa, sehingga memungkinkan siswa untuk berinteraksi dengan lingkungan secara langsung dan benar-benar mengalami proses belajar yang aplikatif.

Materi yang diterapkan dalam penelitian ini adalah materi "Sistem Gerak pada Manusia", yang menjelaskan mengenai organ penyusun sistem gerak pada manusia yang terdiri dari struktur dan fungsi rangka, struktur dan fungsi sendi, struktur dan fungsi otot, kelainan atau penyakit pada sistem gerak serta upaya yang dilakukan untuk menjaga kesehatan sistem 
gerak manusia. Pemilihan materi ini didasarkan karena materinya yang kompleks dan sangat berhubungan dengan kehidupan sehari-hari. Karakteristik materi ini sangat cocok untuk diterapkan dengan pendekatan saintifik yang menuntut siswa agar memahami materi dan dapat menuntaskan hasil belajar sehingga siswa dapat memperoleh kesempatan mengembangkan kemampuan berpikirnya, mengaitkan materi dengan kehidupan sehari-hari, kemampuan bekerja sama dan menjadi pembelajar yang mandiri, selain itu dengan pendekatan saintifik yang bersifat kontekstual dan berpusat pada siswa, maka akan muncul keterlibatan siswa untuk aktif dalam kegiatan belajar sehingga penilaian terhadap siswa dapat mencakup kompetensi sikap dan keterampilan bukan hanya pengetahuan dan hasil belajar siswa sesuai dengan Kurikulum 2013.

Penelitian yang telah dilakukan terkait pembelajaran berbasis pendekatan saintifik hasilnya menunjukkan dampak yang positif bagi siswa, diantaranya adalah penelitian yang dilakukan oleh Marjan (2014) dalam penelitiannya menyatakan bahwa pembelajaran berbasis pendekatan saintifik mampu meningkatkan hasil belajar siswa dan keterampilan proses sains dasar. Selain itu penelitian yang dilakukan Machin (2014) menyatakan bahwa penerapan pendekatan saintifik berpengaruh positif terhadap hasil belajar kognitif, afektif dan psikomotorik serta telah mencapai ketuntasan klasikal yang ditetapkan, yakni lebih dari $85 \%$ dari seluruh siswa yang mengikuti pembelajaran.

Berdasarkan uraian diatas, peneliti menganggap perlu mengadakan penelitian dengan judul "Pengembangan Perangkat Pembelajaran IPA Berbasis Pendekatan Saintifik untuk Menuntaskan Hasil Belajar Siswa Pokok Bahasan Sistem Gerak pada Manusia di SMP”. Perangkat pembelajaran berbasis pendekatan saintifik akan dikembangkan kemudian diujicobakan.

\section{METODEPENELITIAN}

Penelitian ini merupakan penelitian pengembangan (development research) yang bertujuan untuk menghasilkan perangkat pembelajaran meliputi: Rencana Pelaksanaan Pembelajaran (RPP), Buku Ajar Siswa (BAS), Lembar Kegiatan Siswa (LKS), dan Lembar Penilaian sikap, pengetahuan, dan keterampilan, dengan menggunakan pembelajaran berbasis pendekatan saintifik pada pokok bahasan sistem gerak pada manusia. Metode pengembangan perangkat ini merupakan modifikasi dari the four $D$ models yang dikembangkan oleh (Thiagarajan dan Semmel 1974), yaitu: difine, design, develop dan disseminate yang kemudian diadaptasi menjadi model 3-D yaitu: pendefinisian, perancangan dan pengembangan. Rancangan penelitian yang dilakukan pada ujicoba kelas terbatas dan ujicoba kelas normal menggunakan one-group pretest-posttest design dengan pola sebagai berikut:

\section{$\mathrm{O}_{1} \mathrm{X} \mathrm{O}_{2}$}

Keterangan:

$\mathrm{O}_{1}$ adalah uji awal (pretest) untuk mengetahui pengetahuan awal siswa sebelum pembelajaran.

$\mathrm{O}_{2}$ adalah uji akhir (posttest) untuk mengetahui pengetahuan siswa setelah pelaksanaan pembelajaran berbaisis inkuiri terbimbing dengan tugas proyek.

$\mathrm{X}$ adalah perlakuan (treatment) pembelajaran dengan menggunakan perangkat pembelajaran berbasis pendekatan saintifik.

Subjek dalam penelitian ini adalah perangkat pembelajaran IPA berbasis pendekatan saintifik untuk menuntaskan hasil belajar siswa SMP yang dikembangkan peneliti dan subjek ujicoba adalah siswa SMP Negeri Rasiei Kabupaten Teluk Wondama-Papua Barat Kelas VIIIA dan VIIIB semester gasal Tahun Pelajaran 2016/ 2017.

Variabel-variabel dalam penelitian ini adalah: (1) validitas perangkat pembelajaran meliputi RPP, BAS, LKS, dan lembar penilaian; (2) kepraktisan perangkat pembelajaran meliputi keterlaksanaan RPP, aktivitas siswa, serta kendala-kendala yang dihadapi selama proses pembelajaran; dan (3) keefektifan perangkat mengacu pada tes hasil belajar siswa.

Teknik pengumpulan data dilakukan dengan validasi, dokumentasi, pengamatan, pemberian tes, dan pemberian angket. Instrumen penelitian dikembangkan berdasarkan instrumen-instrumen peneliti sebelumnya yang diadaptasi dan disesuaikan dengan kebutuhan peneliti serta dilakukan validasi oleh para ahli untuk memperoleh masukan dan saran sebelum instrumen digunakan. Teknik analisis data menggunakan teknik analisis deskriptif kualitatif.

1. Analisis Validitas Perangkat Pembelajaran

Validitas perangkat pembelajaran model inkuiri terbimbing yang dikembangkan ditentukan berdasarkan hasil penilaian dua validator ahli dengan kriteria penilaian seperti pada Tabel 1.

Tabel 1. Kriteria Pengkategorian Lembar Penilaian

\begin{tabular}{|c|c|lr|}
\hline Interval skor & Kategori & \multicolumn{2}{|c|}{ Keterangan } \\
\hline $\begin{array}{c}1,00 \leq \mathrm{SVP} \leq \\
1,59\end{array}$ & Tidak valid & $\begin{array}{l}\text { Tidak dapat } \\
\text { digunakan dan } \\
\text { masih memerlukan } \\
\text { konsultasi }\end{array}$ \\
\hline $\begin{array}{c}1,60 \leq \mathrm{SVP} \leq \\
2,59\end{array}$ & $\begin{array}{c}\text { Kurang } \\
\text { valid }\end{array}$ & $\begin{array}{l}\text { Dapat digunakan } \\
\text { dengan banyak } \\
\text { revisi }\end{array}$ \\
\hline $\begin{array}{c}2,60 \leq \mathrm{SVP} \leq \\
3,59\end{array}$ & Valid & $\begin{array}{l}\text { Dapat digunakan } \\
\text { dengan sedikit revisi }\end{array}$ \\
\hline $3,60 \leq \mathrm{SVP} \leq$ & Sangat \\
3,59 & valid & $\begin{array}{l}\text { Dapat digunakan } \\
\text { tanpa revisi }\end{array}$ \\
\hline
\end{tabular}

(Ratumanan dan Laurens, 2011)

Hasil penilaian dua orang validator selanjutnya ditindaklanjuti oleh peneliti sesuai dengan saran dan komentar yang diberikanserta dianalisis menggunakan 
analisis statistik precentage of agreementsebagai berikut:

Percentage og Agreements $=\frac{A}{A+D} \times 100 \%$

Keterangan:

$\mathrm{A}=\underset{\text { (Agreement) }}{ }$.

$\mathrm{D}=$ Frekuensi ketidakcocokan antar penilai (Disagreement).

Instrumen dikatakan cocok apabila memiliki Percentage of agreement $>75 \%$ (Borich, 1994).

2. Analisis Kepraktisan Perangkat Pembelajaran

a. Analisis Keterlaksanaan RPP

Analisis Keterlaksanaan RPP dihitung menggunakan rumus:

$$
\mathrm{P}=\frac{\text { jumlah tahap pembelajaran yang dilaksanakan }}{\text { jumlah seluruh tahap pembelajaran }} \times 100 \%
$$
pertemuan akan dikonversikan dalam kategori seperti pada Tabel 2.

Tabel 2. Kategori Persentase Keterlaksanaan RPP

\begin{tabular}{|c|c|}
\hline $\begin{array}{c}\text { Interval } \\
\text { Persentase }\end{array}$ & Kategori \\
\hline $0 \%-24 \%$ & Tidak terlaksana \\
\hline $25 \%-49 \%$ & $\begin{array}{c}\text { Terlaksana kurang } \\
\text { baik }\end{array}$ \\
\hline $50 \%-74 \%$ & Terlaksana baik \\
\hline $75 \%-100 \%$ & Terlaksana sangat baik \\
\hline
\end{tabular}

Penilaian keterlaksanaan RPP ditentukan dengan membandingkan rata-rata penilaian yang diberikan kedua pengamat dengan kriteria penilaian seperti pada Tabel 3.

Tabel 3. Deskripsi Skor Keterlaksanaan Pembelajaran

\begin{tabular}{|c|c|}
\hline Interval SkorRata-rata & Kategori \\
\hline $1,00-1,49$ & Kurang \\
\hline $1,50-2,49$ & Cukup \\
\hline $2,50-3,49$ & Baik \\
\hline $3,50-4,00$ & Baik sekali \\
\hline
\end{tabular}

(Riduwan, 2012)

Skor Keterlaksanaan RPP dihitung dengan menggunakan rumus percentage of agreement (Borich, 1994) sebagai berikut:

$$
\mathrm{R}=\left[1-\frac{A-B}{A+B}\right] \times 100 \%
$$

Keterangan:

$\mathrm{R}=$ Percentage of Agreement .

$\mathrm{A}=$ Skor aspek keterlaksanaan yang teramati dengan skor tinggi.

$\mathrm{B}=$ Skor aspek keterlaksanaan yang teramati dengan skor rendah.

Instrumen dikatakan cocok apabila memiliki tingkat kecocokan antar pengamat > 75\% (Borich, 1994:385).

\section{b. Analisis Aktivitas Siswa}

Aktivitas yang dilakukan siswa selama kegiatan pembelajaran berlangsung dinilai oleh dua pengamat dengan menggunakan instrumen lembar aktivitas siswa. Data yang diperoleh selanjutnya dipersentasekan menggunakan rumus sebagai berikut:

$$
\mathrm{P}=\frac{\sum \mathrm{R}}{\sum \mathrm{N}} \times 100 \%
$$

(Arifin, 2012)

Keterangan:

$\mathrm{P} \quad=$ Persentase aktivitas siswa

$\Sigma \mathrm{R}=$ Frekuensi aktivitas yang muncul dalam

menit

$\Sigma \mathrm{N}=$ Frekuensi keseluruhan siswa dalam menit

Perhitungan reliabilitas aktivitas siswa menggunakan persamaan sebagai berikut:

$$
R=\left(1-\frac{A-B}{A+B}\right) \times 100 \%
$$

(Borich, 1994).

Keterangan:

$\mathrm{R}=$ Pesentase reliabilitas instrumen (percentage of agreement)

A = Skor tertinggi yang diberikan olah pengamat

$\mathrm{B}=$ Skor terendah yang diberikan olah pengamat

Instrumen penilaian perangkat digolongkan reliabel, jika memiliki nilai reliabilitas $\geq 75 \%$ (Borich, 1994).

c. Analisis Kendala Pembelajaran

Kendala-kendala dalam kegiatan pembelajaran dianalisis dengan menggunakan analisis deskriptif kualitatif yaitu pengamat dan peneliti memberikan catatan-catatan tentang hambatan yang terjadi sepanjang kegiatan belajar mengajar serta alternatif pemecahan masalah yang dapat dilakukan.

\section{Analisis Keefektifan Perangkat Pembelajaran a. Analisis Tes Hasil Belajar}

Analisis tes hasil belajar menurut lampiran yang terdapat dalam Permendikbud RI No 53 (2015) tentang panduan penilaian aspek sikap, pengetahuan dan keterampilan di SMP menggunakan skala $0-100$ dengan ketentuan predikat sebagai berikut:

Tabel 4. Konversi Skor dan Predikat Hasil Belajar

\begin{tabular}{|c|c|c|c|}
\hline \multicolumn{3}{|c|}{ Nilai Kompetensi } & \multirow{2}{*}{ Predikat } \\
\hline $\begin{array}{c}\text { SB (Sangat } \\
\text { Baik) }\end{array}$ & Pengetahuan & Keterampilan & \multirow{2}{*}{ A } \\
\hline B (Baik) & $71-85$ & $86-100$ & B \\
\hline C (Cukup) & $56-70$ & $51-85$ & C \\
\hline K (Kurang) & $\leq 55$ & $\leq 55$ & D \\
\hline \multicolumn{4}{|c}{ (Kemendikbud No. 53, }
\end{tabular}

2015)

Kompetensi Dasar (KD) pada Kompetensi Inti (KI) 3 dan KI 4 hasil belajar, dikatakan mencapai ketuntasan secara individu apabila memenuhi Kriteria Ketuntasan Minimum yang ditetapkan yaitu sebesar 70 untuk aspek pengetahuan dan 71 untuk aspek keterampilan dan memiliki predikat minimal B (Baik).

Efektivitas perangkat pembelajaran yang dikembangkan didasarkan pada data hasil pretest dan 
posttest untuk mengetahui ketuntasan hasil belajar siswa. Data tes tersebut dianalisis secara deskriptif kuantitatif menggunakan rumus $\mathrm{N}$-gain. Besarnya peningkatan atau gain dianalisis dengan menggunakan rumus Hake (1999) sebagai berikut:

$$
\langle g\rangle=\frac{\left\langle S_{\text {post }}\right\rangle-\left\langle S_{\text {pre }}\right\rangle}{\left\langle S_{\text {max }}\right\rangle-\left\langle S_{\text {pre }}\right\rangle} \text { Keterangan }
$$

: Nilai gain

Spost : Nilai posttest

Spre : Nilai pretest

Smax : Nilai maksimal

Hasil perhitungan $\mathrm{N}$-gain tersebut kemudian dikonversikan dengan kriteria seperti pada Tabel 5.

Tabel 5. Kriteria Normalized Gain

\begin{tabular}{|c|c|}
\hline Skor Normalized Gain & Kriteria NormalizedGain \\
\hline $0,7<N$-Gain & Tinggi \\
\hline $0,3 \leq N$-Gain $\leq 0,70$ & Sedang \\
\hline$N$-Gain $<0,30$ & Rendah \\
\hline & (Hake, \\
\hline
\end{tabular}

1999)

Indeks sensitivitas butir soal pada dasarnya merupakan ukuran seberapa baik butir tersebut membedakan antara peserta didik yang telah dan yang belum mengikuti kegiatan belajar mengajar (Ratumanan dan Laurens, 2011). Sensitivitas butir soal pemahaman konsep menggunakan rumus menurut Gronlund (1982) sebagai berikut:

Keterangan:

$$
S=\frac{R_{A}-R_{B}}{T}
$$

$\mathrm{S} \quad$ : Sensitivitas butir soal

$\mathrm{R}_{\mathrm{A}}$ : Jumlah siswa yang menjawab benar pada tes akhir

$\mathrm{R}_{B}$ : Jumlah siswa yang menjawab benar pada tes awal

$\mathrm{T}$ : Jumlah seluruh siswa yang mengikuti tes.

Gronlund (1982) menyatakan bahwa butir soal dikatakan sensitif apabila butir soal berharga 0,30 sampai dengan 1,00. Sensitivitas butir soal keterampilan berpikir kritis dihitung dengan menggunakan persamaan:

$$
S=\frac{\sum_{1}^{n} \operatorname{Ses}-\sum_{1}^{n} S e b}{N\left(S k o r_{\max }-S k o r_{\min }\right)}
$$

Keterangan:

S : Sensitivitas butir soal

.$\sum_{1}^{n} \operatorname{Ses}$ :Jumlah skor subyek setelah prosespembelajaran

. $\sum_{1}^{n} \mathrm{Seb}:$ Jumlah skor subyek sebelum proses pembelajaran

$\mathrm{N} \quad$ : Jumlah seluruh siswa yang mengikuti tes

Skor $_{\max }$ : Skor maksimal yang diperoleh siswa

Skor $_{\min } \quad$ : Skor minimal yang diperoleh siswa.

Penilaian keterampilan berupa tugas kinerja

yang dilakukan pada pertemuan 1 sampai pertemua 4 .

Penilaian tugas kinerja ditentukan berdasarkan instrument penilaian tugas kinerja, kemudian skor yang diperoleh dikonversi. Siswa dikatakan tuntas untuk aspek ketarampilan (tugas kinerja) apabila mendapatkan nilai $\geq 71$ dengan predikat B (Baik). Aspek keterampilan menggunakan rumus sebagai berikut:

$$
\text { Nilai Siswa }=\frac{\text { Skor yang diperoleh }}{\text { skor maksimal }} \times 100 \%
$$

\section{b. Analisis Respons Siswa}

Angket respon siswa digunakan untuk mengetahui pendapat siswa terhadap penerapan perangkat pembelajaran yang dikembangkan. Respon siswa dianalsis secara deskriptif menggunakan persamaan sebagai berikut:

$$
\mathrm{P}=\frac{\sum \mathrm{K}}{\sum \mathrm{N}} \times 100 \%
$$

$=$ Persentase respon siswa

= Jumlah siswa yang memilih jawaban dengan

kategori pilihan yang ada

$=$ Jumlah siswa yang mengisi angket

Persentase respon siswa yang didapat, selanjutnya dikonversi dengan kriteria sebagai berikut: Angka 0\% - 20\% : Negatif (Sangat lemah)
Angka 21\% - 40\%
Angka 41\%-60\%
: Negatif (Lemah)
Angka 61\%-80\%
: Cukup
Angka 81\% - 100\%
: Positif (Kuat)
: Positif (Sangat Kuat)

(Riduwan, 2012)

\section{HASIL PENELITIAN DAN DISKUSI}

Penelitian ini merupakan pengembangan dan penerapan perangkat pembelajaran berbasis inkuiri terbimbing dengan tugas proyek pada materi sistem ekskresi untuk ketuntasan hasil belajar siswa SMP. Pengembangan perangkat pembelajaran menggunakan Kurikulum 2013 meliputi: 1) Rencana Pelaksanaan Pembelajaran (RPP); 2) Lembar Kegiatan Siswa (LKS); 3) Buku Ajar Siswa (BAS); dan 4) Instrumen penilaian hasil belajar yang terdiri dari: instrumen penilaian sikap, instrumen penilaian hasil belajar aspek pengetahuan, dan instrumen penilaian hasil belajar siswa pada aspek keterampilan dalam hal ini tugas kinerja. Pemilihan model pengembangan perangkat dengan modifikasi dari the four $D$ models yang dikembangkan oleh (Thiagarajan dan Semmel 1974), yaitu: difine, design, develop dan disseminate yang kemudian diadaptasi menjadi model 3-D yaitu: pendefinisian, perancangan dan pengembanganPenelitian ini mengembangkan perangkat dengan menggunakan Kurikulum 2013 dan secara ringkas hasil pengembangan perangkat pembelajaran berbasis pendekatan saintifik disajikan sebagai berikut:

\section{A. Validasi perangkat Pembelajaran \\ 1. Hasil Validasi RPP}

Rencana Pelaksanaan Pembelajaran (RPP) diartikan sebagai persiapan mengajar yang oprasional, 
rinci, dan siap untuk diimplementasikan (Kardi, 2012). Hasil validasi RPP yang dilakukan oleh dua orang validator ahli didapatkan rata-rata hasil validasi dari semua aspek sebesar 3,67 sehingga dikategorikan valid, (Ratumanan \& Laurens, 2011)., sedangkan ratarata percentage of agreement antar tiga validator sebesar 96,97 \% (Borich, 1994). Hasil tersebut menunjukkan bahwa RPP yang dikembangkan secara umum masuk kategori valid dan layak digunakan dalam pembelajaran setelah melalui tahap revisi sesuai saran dari validator ahli. RPP yang dikembangkan masuk kategori layak atau valid, karena penyusunannya mengacu pada Permendikbud No. 103 Tahun 2014 yang di dalamnya memuat beberapa komponen RPP antara lain: identitas sekolah, mata pelajaran, kelas/semester, alokasi waktu, Kompetensi Inti (KI), Kompetensi Dasar (KD), indikator pencapaian kompetensi, materi pembelajaran, kegiatan pembelajaran, penilaian, dan media/ alat, bahan, serta sumber belajar. Kegiatan pembelajaran yang terdapat dalam RPP disesuaikan dengan tahaptahap pendekatan saintifik. Perpaduan ini diharapkan dapat menjadi pembelajaran yang dapat mengintegrasikan sikap, pengetahuan, dan keterampilan sehingga dapat membekali siswa dengan kompetensi IPA yang utuh.

2. Hasil Validasi Lembar Kerja Siswa

Lembar kerja siswa adalah suatu bahan ajar cetak berupa lembar-lembar kertas yang berisi materi, ringkasan dan petunjuk-petunjuk pelaksanaan tugas pembelajaran yang harus dikerjakan oleh peserta didik, yang mengacu pada kompetensi dasar yang harus dicapai (Prastowo, 2012). Pada penelitian ini disusun tiga LKS untuk tiga kegiatan penyelidikan dengan menggunakan pendekatan saintifik yaitu LKS 01 (penyelidikan tentang struktur dan fungsi tulang), LKS 02 (penyelidikan tentang struktur dan fungsi sendi), LKS 03 (penyelidikan tentang struktur dan fungsi otot). Validasi LKS dilakukan pada aspekaspek antara lain; format, isi, dan bahasa. Hasil penilaian dari tiga validator yang terdiri dari semua aspek penilaian dengan masing-masing aspek didapatkan rata-rata hasil validasi sebesar 3,50 dinyatakan valid (Ratumanan \& Laurens, 2011). Ratarata percentage of agreement antar tiga validator sebesar $91,75 \%$ sehingga dikategorikan cocok karena $\geq 75 \%$ (Borich, 1994). Hasil tersebut secara umum menunjukkan bahwa LKS yang dikembangkan peneliti layak digunakan pada proses pembelajaran.

\section{Hasil Validasi Buku Ajar Siswa}

Bahan ajar merupakan seperangkat materi atau substansi pembelajaran (teaching material) yang disusun secara sistematis dan menampilkan sosok utuh dari kompetensi secara runtut dan sistematis (Prastowo, 2013). Buku ajar siswa merupakan salah satu bentuk media cetak, pengembangan buku siswa dilakukan dengan mengikuti tahapan tertentu, yaitu penentuan Kompetensi Dasar, pemilihan materi, format, bahasa dan tampilan fisik. Buku siswa digunakan sebagai sumber pengembangan konsep pada materi sistem ekskresi dalam proses pembelajaran. Hasil validasi BAS dari kedua validator dapat diketahui bahwa rata-rata hasil validasi pada semua aspek memperoleh skor sebesar 3,33 sehingga dikategorikan valid, (Ratumanan \& Laurens, 2011). Rata-rata percentage of agreement antar tiga validator sebesar 91,84\% sehingga dikategorikan cocok karena $\geq 75 \%$ (Borich, 1994). Hasil validasi tersebut menunjukkan bahwa buku ajar siswa yang telah dikembangkan layak untuk dijadikan panduan siswa maupun guru dalam proses pembelajaran setelah direvisi sesuai dengan saran validator ahli. Perbaikan yang disarankan meliputi: perbaikan kalimat yang disesuaikan dengan ejaan yang baik dan benar, perubahan susunan penyampaian dan penambahan beberapa materi, serta perbaikan beberapa gambar dalam BAS. BAS yang disusun dapat dikategorikan layak karena telah disesuaikan dengan panduan penyusunan bahan ajar oleh Depdiknas (2008) dengan komponen BAS yang meliputi meliputi kesesuaian uraian materi dengan kompetensi yang akan dicapai, keakuratan materi, teknik penyajian, dan pendukung penyajian.

\section{Hasil Validasi Instrumen Penilaian \\ a. Hasil Validasi Penilaian sikap}

Instrumen penilaian sikap siswa adalah instrumen penilaian dengan lembar pengamatan sikap selama proses pembelajaran dengan menggunakan perangkat pembelajaran berbasis ingkuiri terbimbing dengan tugas proyek. Instrumen penilaian sikap digunakan untuk mendata sikap siswa selama kegiatan pembelajaran berlangsung. Instrumen penilaian sikap dikembangkan oleh peneliti dengan mangadaptasi dan mengacu pada instrumen penilaian permendikbud No 53 tahun 2015. Hasil validasi penilaian aspek sikap dapat diketahui bahwa rata-rata skor validasi isi dan bahasa masing-masing 3,83 dan 3,67 dengan kategori sangat valid (Ratumanan \& Laurens, 2011). Sedangkan rata-rata percentage of agreement antar tiga validator sebesar 92,86\% sehingga dikategorikan cocok karena $\geq 75 \%$ (Borich, 1994). Instrumen penilaian ini masuk kategori valid karena dalam penyusunannya didasarkan pada Permendikbud No. 53 Tahun 2015. Instrumen penilaian aspek sikap yang dikembangkan berupa jurnal. Perilaku yang baik atau kurang baik dideskripsikan dalam jurnal tersebut tidak terbatas pada butir-butir nilai sikap yang hendak ditanamkan melalui pembelajaran yang saat itu sedang berlangsung sebagaimana dirancang dalam RPP. Predikat penilaian sikap terdiri dari empat skala yaitu: $\mathrm{SB}=$ sangat baik, $\mathrm{B}=$ baik, $\mathrm{C}=$ cukup dan $\mathrm{K}=$ kurang .

\section{b. Hasil Validasi Penilaian pengetahuan}

Tes hasil belajar yang dikembangkan oleh peneliti digunakan untuk mengukur aspek pengetahuan (penguasaan konsep) siswa. Butir soal disusun berdasarkan pada Permendikbud No. 53 tahun 2015 dan berpedoman pada aspek pengetahuan taksonomi 
Bloom revisi (Anderson \& Krathwohl dalam Manuhutu, 2001) yang meliputi kemampuan memahami (C2), menerapkan (C3), menganalisis (C4), mengevaluasi (C5), dan menciptakan (C6) pada materi sistem ekskresi. Soal tes dibuat sebanyak 25 soal yang terdiri dari 20 butir soal pilihan ganda dan 5 butir soal uraian yang merujuk pada indikator. Hasil validasi instrumen penilaian aspek pengetahuan dari aspek isi mendapatkan rata-rata hasil validasi sebesar 3,58 dan dikategorikan valid, dan rata-rata hasil validasi aspek bahasa sebesar 3,55 dan dikategorikan sangat valid (Ratumanan \& Laurens, 2011). Rata-rata percentage of agreement antar tiga validator sebesar 93,21\% sehingga dikategorikan cocok karena $\geq 75 \%$ (Borich, 1994). Hasil tersebut menunjukkan bahwa tes pengetahuan yang dikembangkan layak digunakan sebagai alat ukur guna mengukur tingkat penguasaan pengetahuan pada materi sistem ekskresi pada siswa, karena penyusunan tes pengetahuan telah mengacu pada indikator dikembangkan dan sesuai dengan saran dari validator. Saran dari validator ahli terkait perbaikan butir soal meliputi kata operasional dari soal disesuaikan dengan tingkat kognitif revisi Bloom, perbaikan redaksi bunyi soal, gambar soal diperjelas dan penyempurnaan pilihan jawaban pada soal pilihan ganda. Setelah direvisi sesuai dengan saran validator, instrumen tes aspek pengetahuan dapat digunakan dalam proses pembelajaran.

c. Hasil Validasi penilaian Keterampilan

Penyusunan lembar penilaian keterampilan kinerja didasarkan atas sembilan tahapan yang merujuk pada teknik penilaian proyek Permendikbud Nomor 53 Tahun 2015 yang meliputi persiapan, perumusan judul, sistematika penulisan, keakuratan sumber data/informasi, kuantitas sumber data, penarikan kesimpulan, performan, presentasi/penguasaan materi, dan produk sedangkan kriteria penilaian dikembangkan sendiri oleh peneliti. Validasi instrumen penilaian tugas proyek meliputi isi dan bahasa. Berdasakan hasil validasi aspek isi memperoleh rata-rata skor 3,67 dengan kategori valid dan aspek bahasa sebesar 3,61 dengan kategori valid (Ratumanan \& Laurens, 2011). Sedangkan rata-rata percentage of agreement antar tiga validator sebesar $89,68 \%$ sehingga dikategorikan cocok karena $\geq 75 \%$ (Borich, 1994). Instrumen penilaian tugas proyek ini dikategorikan layak digunakan sebagai panduan penilaian.

\section{B. Data Hasil Ujicoba}

\section{Analisis Keterlaksanaan RPP}

Analisis data hasil pengamatan keterlaksanaan pembelajaran diketahui bahwa persentase keterlaksanaan tahapan pembelajaran pada pertemuan ke-1sampai dengan pertemuan ke-4 sebesar $100 \%$ dengan kategori keterlaksanaan sangat baik. Hasil persentase tersebut menunjukkan bahwa seluruh tahap pembelajaran yang dilaksanakan masuk kategori sangat baik dengan rentang rata-rata skor setiap tahap antara 3,42 - 4,0. Rata-rata kecocokan pengamat (Percentage of agreement) sebesar 98,22\% dengan kategori sangat baik (Borich, 1994). Hasil penilaian keterlaksanaan pembelajaran disajikan dalam bentukGambar 1 .

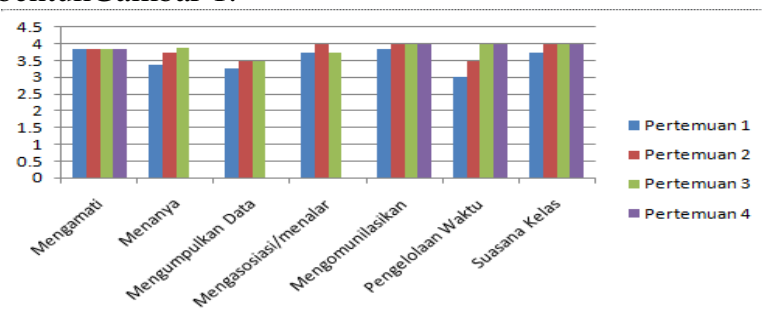

Gambar 1. Diagram Penilaian Keterlaksanan Pembelajaran

\section{Analisis Aktivitas Siswa}

Aktivitas siswa dalam penelitian ini merupakan rangkaian kegiatan yang dilakukan siswa selama mengikuti kegiatan pembelajaran meliputi: (1) mengamati, (2), menanya, (3) Mengumpulkan data, (4) mengasosiasi, (5) mengomunikasikan, (6) meminta bimbingan kepada guru, (7) tindakan yang tidak relevan.

Berdasarkan hasil analisis data pengamatan aktivitas siswa yang memiliki persentase aktivitas yang tinggi dan mengalami peningkatan persentase setiap pertemuannya yaitu aktivitas yaitu pada kegiatan mengamati, menanya, mengumpulkan data, mengasosiasi, dan mengomunikasi. Aktivitas tersebut merupakan aktivitas yang berpusat kepada siswa, hal ini menunjukkan bahwa pembelajaran berbasis pendekatan saintifik merupakan pembelajaran yang mengedepankan peran aktif siswa, siswa membangun sendiri. Peningkatan aktivitas siswa terjadi akibat adanya bantuan (scaffolding) yang dilakukan oleh guru seperti memberikan bantuan kepada siswa yang mengalami kesulitan dalam memahami pertanyaan, memberikan informasi kegiatan pembelajaran yang harus dilakukan, dan membimbing siswa dalam menarik suatu kesimpulan, pada akhirnya siswa akan terlatih untuk menyelesaikan tugas-tugas dengan sedikit atau tanpa bantuan dari guru, hal ini dapat dilihat persentase bimbingan guru mengalami penurunan dari setiap pertemuannya dari rentang nilai $19,5 \%$ turun menjadi $7,2 \%$. Hal ini menunjukkan bahwa guru memberikan bantuan kepada siswa dikurangi tahap demi tahap, sehingga siswa pada akhirnya terbiasa dengan sendirinya. Ide bantuan (scaffolding) didasarkan atas teori Brunner, bahwa anak-anak menggunakan bantuan sebagai dukungan sementara membangun pemahaman yang kuat yang pada akhirnya memungkinkan untuk mengatasi masalahnya (Wolfolk, 2009).

Aktivitas siswa yang mengalami penurunan dalam setiap pertemuan yaitu meminta biimbingan guru, dan tindakan yang tidak relevan. Hal ini memberi gambaran bahwa pada pertemuan pertama siswa memerlukan banyak bimbingan dari guru dalam proses inkuiri, karena siswa tidak terbiasa melakukan proses $5 \mathrm{M}$, pada pertemuan pertama guru berusaha memberi motivasi dan menciptakan suasana pembelajaran yang menyenangkan, memberi masukan 
pada siswa bahwa proses ini akan sangat bermanfaat dalam menyelesaikan masalah. Pada pertemuan selanjutnya secara berkala guru mengurangi bimbingan pada siswa, karena secara berkala siswa sudah mulai terbiasa dengan proses pembelajaran berbasis pendekatan saintifik, dan pada pertemuan terakhir peran guru sepenuhnya hanya sebagai fasilitator.

Persentase aktivitas siswa yang tidak relevan dengan pembelajaran mengalami penurunan dari setiap pertemuan yaitu dari $3.39 \%$ menjadi $1,1 \%$. Hal ini menunjukkan suasana belajar yang diciptakan dapat menarik antusiasme siswa sehingga siswa fokus pada kegiatan pembelajaran. Ketika siswa tertarik pada pembelajaran dan melibatkan diri secara aktif dalam kegiatan pembelajaran maka siswa cenderung tidak akan melakukan akivitas yang kurang relevan (Aydin dan Yilmaz, 2010). Aktivitas yang tidak relevan ini adalah aktivitas yang tidak diinginkan selama proses pembelajaran berlangsung yaitu seperti tidak dapat bekerja sama dengan teman satu kelompok, tidak dapat menyatakan pendapat dengan bahasa yang baik dan kurang disiplin. Aktivitas siswa yang tidak relevan seperti tidak dapat bekerjasama dengan teman satu kelompok maka pada pertemuan berikutnya siswa tersebut diberi tugas yang lebih mudah dalam melakukan percobaan agar dapat bertanggung jawab dan berinteraksi dengan teman satu kelompok. Keseluruhan aktivitas siswa dapat digambarkan pada diagram berikut:

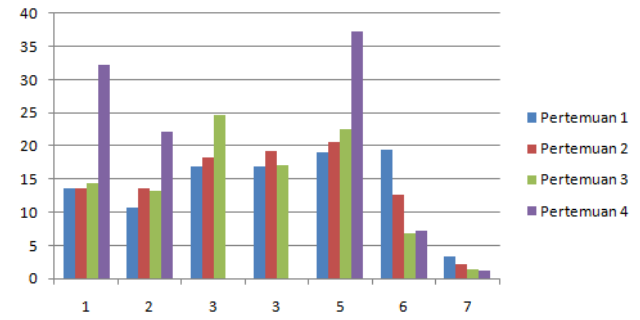

Gambar 2. Diagram Aktivitas siswa

\section{Analisis Kendala Pembelajaran}

Kendala-kendala yang dihadapi selama proses pembelajaran berbasis inkuiri terbimbing dengan tugas proyek disajikan pada Tabel 6 .

Tabel 6. Kendala-kendala Selama Proses Pembelajaran

\begin{tabular}{|l|l|}
\hline \multicolumn{1}{|c|}{ Kendala } & \multicolumn{1}{|c|}{ Solusi } \\
\hline $\begin{array}{l}\text { Siswa belum terbiasa } \\
\text { mengikuti pembelajaran } \\
\text { berbasis saintifik. }\end{array}$ & $\begin{array}{l}\text { Memberikan dan } \\
\text { pengarahan } \\
\text { informasi kepada siswa } \\
\text { tentang pendekatan } \\
\text { saintifik. }\end{array}$ \\
\hline $\begin{array}{l}\text { Tidak semua sisa aktif } \\
\text { dalam proses KBM } \\
\text { terutama pada saat } \\
\text { melakukan percobaan } \\
\text { serta mengerjakan LKS, } \\
\text { sebagian dari mereka }\end{array}$ & $\begin{array}{l}\text { Guru mengingatkan } \\
\text { dengan bekerja sama } \\
\text { melakukan teman }\end{array}$ \\
\hline
\end{tabular}

\begin{tabular}{|l|l|}
\hline sering mengganggu & $\begin{array}{l}\text { penyelidikan dengan } \\
\text { tepat dan benar. }\end{array}$ \\
teman lain.
\end{tabular}

\section{Ketuntasan hasil belajar \\ a. Sikap}

Hasil belajar aspek sikap diperoleh melalui data hasil pengamatan terhadap perilaku yang baik dan kurang baik yang muncul pada siswa selama pembelajaran berlangsung dan dideskripsikan didalam jurnal pengamatan sikap. Sikap yang diamati meliputi sikap spritual yaitu rasa syukur dan sikap sosial yang meliputi jujur dan rasa ingin tahu. Berdasarkan hasil pengamatan dapat diketahui bahwa sikap spritual siswa yaitu rasa syukur dari 23 siswa menunjukkan perilaku rasa syukur yang sangat baik, dan sikap sosial (jujur dan rasa ingin tahu) menunjukkan sikap sosial yang sangat baik, baik dan meningkat. (Kemendikbud No. 53, 2015).

\section{b. Pengetahuan}

Tes hasil belajar aspek pengetahuan dilakukan untuk mengukur ketercapain kompetensi siswa sesuai indikator pembelajaran. Tes aspek pengetahuan dilakukan sebelum (pre-test) dan sesudah (post-test) proses pembelajaran dengan menggunakan pembelajaran berbasis inkuiri terbimbing dengan tugas proyek. Pretest dimaksudkan untuk menyiapkan siswa dalam proses belajar, mengetahui tingkat kemajuan siswa sehubungan dengan proses pembelajaran yang dilakukan, mengetahui kemampuan awal siswa, dan mengetahui tujuan pembelajaran yang perlu mendapatkan penekanan dan perhatian khusus (Mulyasa, 2013). Post-test dilakukan dengan tujuan untuk mengetahui hasil belajar siswa setelah dilakukan pembelajaran.

Berdasarkan analisis hasil tes aspek pengetahuan, dapat diketahui bahwa persentase ketuntasan siswa pada saat pre-test sebesar $0 \%$ yang artinya semua siswa belum mencapai ketuntasan. Hal ini terjadi karena siswa belum mengikuti pembelajaran pada materi sistem ekskresi yang diujikan sehingga jawaban mereka hanya berdasarkan pengetahuan awal atau bahkan perkiraan siswa. Hasil pre-test siswa berkebalikan dengan hasil post-test yang menunjukkan persentase ketuntasan hasil belajar siswa siswa sebesar $100 \%$ baik secara individual maupun klasikal. Seluruh siswa yang mengikuti pembelajaran dengan pembelajaran berbasis inkuiri terbimbing dengan tugas proyek dapat mencapai ataupun melebihi skor minimal yang ditetapkan sekolah yaitu 70, karena seorang siswa dikatakan tuntas belajarnya jika nilainya telah mencapai $\geq 71$ (Kemendikbud No. 53, 2015). Ketuntasan seluruh siswa ini sangat berkaitan dengan keaktifan siswa untuk terlibat dalam proses pembelajaran. Siswa dapat belajar dan menyerap ilmu dengan baik jika mereka dapat terlibat aktif dalam proses pembelajaran (Bruner dalam Slavin, 2011).

Data ketuntasan pre-test dan post-test yang telah dipaparkan di atas menunjukkan adanya peningkatan pemahaman dan pengetahuan siswa tentang materi 
sistem ekskresi. Peningkatan tersebut juga dapat diketahui melalui hasil penghitungan rata-rata $N$-gain yaitu sebesar 0,71 dengan kategori sedang (Hake, 1999). Meningkatnya hasil belajar berarti ini menandakan bahwa siswa telah mengikuti pembelajaran berbasis pendekatan saintifik yang dibuktikan dengan adanya perubahan hasil belajar siswa kearah yang lebih baik. Hal ini menunjukkan bahwa pembelajaran dengan menggunakan perangkat pembelajaran berbasis pendekatan saintifik yang dikembangkan efektif dalam peningkatan ketuntasan hasil belajar siswa. Hal ini sesuai dengan penelitian Machin (2014) yang menyatakan bahwa pembelajaran yang berbasis pendekatan saintifik berpengaruh positif terhadap hasil belajar kognitif siswa dan membuat hasil belajar siswa telah mencapai ketuntasan klasikal yang diharapkan.

Sensitivitas butir soal digunakan untuk mengkategorikan butir-butir soal yang termasuk dalam kategori baik, kurang baik, dan jelek, sehingga didapatkan informasi mengenai baik-tidaknya suatu butir soal, sekaligus memperoleh petunjuk untuk melakukan perbaikan (Ratumanan \& Laurens, 2011). Sensitivitas butir soal yang telah dianalisis menunjukkan perolehan skor dengan rentang 0,3 sampai 0,7 dan semua soal dinyatakan sensitif (Gronlund \& Linn, 1995). Sebanyak 20 butir soal yang diujikan ternyata memiliki kepekaan yang cukup terhadap efek pembelajaran yang diberikan terhadap proses pembelajaran dengan menggunakan pembelajaran berbasis pendekatan saintifik, sehingga dapat dinyatakan bahwa tes pengetahuan tersebut layak digunakan sebagai instrumen untuk mengukur penguasaan konsep siswa.

Berdasarkan data pada Tabel 4.16 menunjukkan bahwa semua siswa yang diberikan pre-test tidak mencapai ketuntasan hasil belajar siswa, hal ini dilihat dari rata-rata nilai pre-test sebesar 26,09 dengan predikat kurang. Setelah diberikan perlakuan dengan melalui pembelajaran berbasis pendekatan saintifik kemudian diberikan post-test maka semua nilai siswa tuntas, hal ini dapat dilihat rata-rata nilai post-test siswa sebesar 78,91 dengan predikat baik (Permendikbud No 53 Tahun 2015). Ketuntasan hasil belajar siswa disajikan dalam bentuk grafik pada Gambar 3. sebagai berikut:

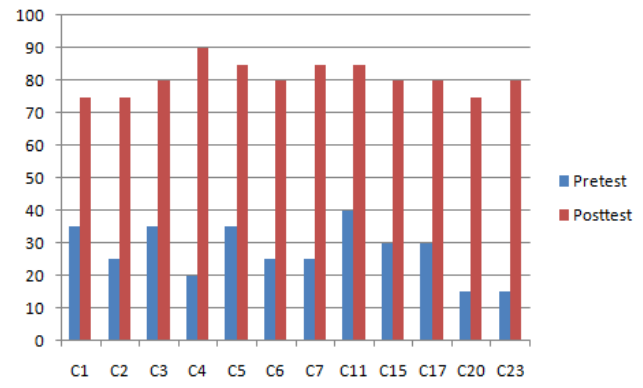

Gambar 3. Diagram Ketuntasan Hasil Belajar Pada Aspek Pengetahuan

\section{c. Hasil Belajar Keterampilan}

Penilaian keterampilan merupakan penilaian yang dilakukan untuk mengetahui kemampuan siswa dalam menerapkan pengetahuan untuk melakukan tugas tertentu didalam berbagai konteks sesuai dengan indikator pencapaian kompetensi (Kemdikbud No. 53 Tahun 2015). Teknik penilaian keterampilan yang peneliti gunakan adalah penilaian kinerja, dimana penilaian ini dilakukan untuk mengukur capaian pembelajaran berupa keterampilan proses dan/ atau hasil (produk).

Penilaian keterampilan diambil berdasarkan kinerja siswa dalam membuat karya tulis (makalah) pada pertemuan 1-4 yang meliputi persiapan, rumusan judul, sistematika penulisan, keakuratan sumber data/informasi, kuantitas sumber data, penarikan kesimpulan, performan, presentasi/penguasaan materi dan produk. Berdasarkan Tabel 4.18, dapat diketahui bahwa rata-rata nilai aspek keterampilan siswa selama empat kali pertemuan sebesar 77,44 dengan kategori baik. Dengan demikian dapat disimpulkan bahwa pembelajaran dengan menggunakan pendekatan saintifik efektif untuk melatihkan ketrampilan kerja ilmiah. Hal ini sesuai dengan pendapat Machin (2014) bahwa keterampilan kerja ilmiah diperoleh melalui kegiatan mengamati, menanya, mencoba, menalar menyaji, bereksperimen dan mencipta.

\section{Respon Siswa Terhadap Pembelajaran Berbasis Pendekatan Saitifik}

Berdasarkan analisis deskriptif respon siswa terhadap pengembangan komponen pembelajaran dengan menggunakan pendekatan saintifik siswa merespon sangat positif. Pada Tabel 4.13 diperoleh bahwa siswa berpendapat tertarik sebesar 98,9\% dan berpendapat tidak tertarik sebesar $1,1 \%$ terhadap komponen kegiatan pembelajaran yang meliputi materi/isi pelajaran, Lembar kegiata siswa (LKS), Buku Ajar Siswa (BAS), pendekatan dan metode pembelajaran, cara guru mengajar, kegiatan belajar di dalam kelas dan tes hasil belajar. Tabel tersebut juga menunjukkan bahwa siswa merasa baru terhadap komponen pembelajaran sebesar $98,14 \%$. Siswa mudah memahami bahasa dalam buku ajar siswa dan LKS, merasa terarik dengan isi dan kegiatan dalam buku ajar dan LKS sebesar 99,13\%. Siswa merasa tertantang untuk mempelajari materi selanjutnya, siswa menjadi lebih aktif untuk bertanya, siswa berupaya keras untuk membangun ide atau konsep tentang materi yang yang dipelajari, siswa lebih percaya diri untuk menyampaikan ide/pendapat kepada guru/teman sebesar 98,26\%. Siswa berminat dengan penggunaan pembelajaran berbasis saintifik pada pokok bahasan selanjutnya dan pada pelajaran lain sebesar $100 \%$. Siswa merasa baru terhadap tahapan pendekatan saintifik yang dimulai dari fase mengamati, menanya, mengumpulkan informasi, mengasosiasi, dan mengkomunikasikan sebesar $97,39 \%$. Pendapat siswa terhadap penjelasan dan bimbingan guru adalah jelas sebesar $100 \%$. 


\section{PENUTUP}

\section{A. Simpulan}

Berdasarkan analisis, pembahasan temuan hasil penelitian dapat disimpulkan bahwa perangkat pembelajaran IPA berbasis pendekatan saintifik layak (valid, praktis, dan efektif) digunakan untuk menuntaskan hasil belajar siswa pada pokok bahasan sistem gerak manusia.

\section{B. Saran}

Berdasarkan hasil penelitian yang telah dilakukan, beberapa saran dapat dikemukakan oleh peneliti antara lain:

1. Berdasarkan analisis hasil belajar siswa, disarankan pada peneliti berikutnya yang ingin melakukan penelitian yang sama pada materi IPA yang berbeda dengan melakukan penyesuaianpenyesuaian tertentu sesuai materi yang dipilih.

2. Guru dalam memberikan tugas untuk penilaian keterampilan sebaiknya memberikan dalam bentuk tertulis, hindari memberikan perintah kepada siswa dalam bentuk lisan.

3. Perangkat yang dikembangkan sudah layak (valid, praktis dan efektif) untuk diterapkan, namun perlu penyesuaian-penyesuaian jika diterapkan pada sekolah yang kondisinya berbeda.

\section{DAFTAR PUSTAKA}

Aiken, L. (1997). Psichology Testing and Assesment. Ninth Edition. USA: Allyn and Bacon.

Akbar, Sa'dun. (2013). Instrumen Perangkat Pembelajaran. PT.Remaja Rosdakarya: Bandung.

Arends, R.I. (2012). Learning to Teach. New York: McGraw-Hill.

Arikunto, Suharsini. (2010). Prosedur Penelitian: Suatu Pendekatan Praktik. Jakarta: Rineka Cipta.

Arifin, Zaenal. (2012). Evaluasi Pembelajaran. Bandung: PT Remaja Rosda Karya.

Anderson, Lowrin W dan Krathwohl, David R. (2001). A Taxonomy for Learning Teaching and Assesing A Revision Taxonomy of Educational Objectives Complete Edition, New York: David McKay Company, Inc.

Aydin, N., Yilmaz, A. (2010). The Efffect of Constructivist Approach in Chemistry Education on Student's Higher Order Cognitive Skill. H. U. Journal of Education, Vol 39, pp 57-68. [diakses 11-08-2016]

Borich, D. Gary. (1994). Observation Skills for Effective Teaching. New York: Macmillan Publishing Company

Cahyo, A. N. (2013). Panduan Aplikasi Teori-teori Belajar Mengajar. Jogjakarta: DIVA Press.
Daryanto. (2014). Pendekatan Pembelajaran Saintifik Kurikulum 2013. Yogyakarta: Penerbit Gava Media

Dimyati dan Mudjiono. (2006). Belajar dan Pembelajaran. Jakarta: Rineka Cipta.

Djamarah, Saiful, B. (2002). Psikologi Pendidikan. Jakarta: Rineka Cipta.

Dyamarah, dan Zain. 2(006). Strategi Belajar Mengajar. Jakarta: Rineka Cipta.

Depdiknas. (2008). Panduan Pengembangan Bahan Ajar

Edwars, K dan Loveridge, J. (2011). Looking Intro Early Childhood Teacher Support of Children's Scientific Learning. Jurnal Viktoria Univesitas. Auatralia of Early Childhood.

Fauziah, dkk. (2013). Pembelajaran Saintifik Elektronika Dasar Berorientasi Pembelajaran Berbasis masalah. Jurnal INVOTEC Vol.IX(2): 165-178n[diakses 146-2016].

Gronlund, NE. (1995). Constructing Achievment Test, USA: Prentice-Hall Inc.

Kementerian Pendidikan dan Kebudayaan. (2013). Ilmu Pengetahuan Alam/ Kementerian Pendidikan dan Kebudayaan. Jakarta: Kementerian Pendidikan dan Kebudayaan.

Kementerian Pendidikan dan Kebudayaan. (2013). Modul Pelatihan Implementasi Kurikulum 2013. Jakarta: Kementerian Pendidikan dan Kebudayaan.

Kementerian Pendidikan dan Kebudayaan. (2014). Permendikbud Nomor 58 Tahun 2014 Tentang Standar Proses. Jakarta: Kementerian Pendidikan dan Kebudayaan.

Kementerian Pendidikan dan Kebudayaan. (2015). Permendikbud Nomor 53 Tahun 2015 Tentang Panduan Penilaian untuk Sekolah Menengah Pertama (SMP). Jakarta: Kementerian Pendidikan dan Kebudayaan.

Kementerian Pendidikan dan Kebudayaan. (2013). Permendikbud Nomor 65 Tahun 2013 Standar proses Pendidikan Dasar dan Menengah. Jakarta: Berita Negara Tahun 2013.

Kementerian Pendidikan dan Kebudayaan. (2013). Permendikbud Nomor 68 Tahun 2013 Tentang Kurikulum Untuk SMP/Mts. Jakarta: Berita Negara Tahun 2013.

Kementerian Pendidikan dan Kebudayaan. (2013). Permendikbud Nomor 81A Tahun 2013 Implementasi Kurikulum. Jakarta: Berita Negara Tahun 2013.

Kementerian Pendidikan dan Kebudayaan. (2013). Permendikbud Nomor 71 Tahun 2013 Buku Teks Pelajaran Dan Buku Panduan Guru Untuk Pendidikan Dasar Dan Menengah. Jakarta: Berita Negara Tahun 2013.

Koes,H.S. (2003). Strategi Pembelajaran Fisika. Jica. Universitas Negeri Malang 
Kosasih, E. (2015). Strategi Belajar dan Pembelajaran Implementasi Kurikulum 2013. Bandung: Penerbit Yrama Widya.

Kurniasih, Imas dan Sani, Berlin. (2014). Sukses Mengimplementasikan Kurikulum 2013. Kata Pena.

Machin, A. (2014). Implementasi Pendekatan Saintifik, Penanaman Karakter dan Konservasi Pada Pembelajaran Materi

Marsitah dan Nur, Mohamad. (2004). Teori Perkembangan Sosial dan Perkembangan Moral. Surabaya: Pusat Sains dan Matematika Sekolah Universitas Negeri Surabaya.

Minner, D. Levy, A and Century, J. (2010).” Inquiry based science instructions what isit and does it matter? Result from a research synthesis years 1984 to 2002". Journal of Research in Science Teaching. Vol.47 No.2, pp. 474-496.

Mckinley, M dan O'Loughlin, V.D. (2008). Human Anatomy. McGraw-Hill International Edition: America.

Niron, Maria Dominika. (2009). "Pengembangan Silabus dan Rencana Pelaksanaan Pembelajaran dalam KTSP”. Makalah disajikan pada Latihan Profesi Guru dala Jabatan Universitas Negeri Yogyakarta, Yogyakarta.

Nieveen, Nienken. (1999). Proptotyping to reach product quality. Dalam Akker. J.V.D. Design approach and tools in education and training. Washington: Nasional Academy Press.

NRC (National Research Council). (1999). Inquiry and The National Science Education Standards: A Guide for Teaching and Learning. Washington: National Academy Press.

Nur, M. (2008). Pengajaran Berpusat Kepada Siswa dan Pendekatan Konstruktivis dalam Pengajaran. Surabaya: Pusat Sains dan Matematika Sekolah Universitas Negeri Surabaya.

Nur, Mohamad dan Wikandari, Prima Retno. (2008). Pengajaran Berpusat pada Siswa dan Pendekatan Konstruktivis dalam Pengajaran. Surabaya: Pusat Sains dan Matematika Sekolah Universitas Negeri Surabaya.
Pertumbuhan. Jurnal Pendidikan IPA Indonesia. Vol 3 (1)

Marjan, dkk. (2014). Pengaruh Pembelajaran Pendekatan Saintifik Terhadap Hasil Belajar Biologi dan Keterampilan Proses Sains Siswa Mu'allimat Nam Pancor Selong Kabupaten Lombok Timur Nusa Tenggara Barat. e-Journal Program Pasca Sarjana Universitas Pendidikan Ganesha. Vol 4 (1).

Ratumanan, Tanwey Gerson dan Laurens, Theresia. (2011). Penilaian Hasil Belajar pada Tingkat Satuan Pendidikan Edisi 2. Surabaya: Unesa University Press.

Riduwan. (2012). Skala Pengukuran Variabelvariabel Penelitian. Bandung: Alfabeta.

Sadijan. 2014. Pembelajaran Biologi dengan pendekatan Saintifik pada Implementasi Kurikulum 2013. Jurnal Pendidikan Biologi. Vol 11 (1):hal.20-26.

Sanjaya,W. 2007. Strategi Pembelajaran Berorientasi Standar Proses Pendidikan. Jakarta: Kencana.

Santrock, John W. 2008. Educational Psychology. $2^{\text {nd }}$ Edition Edisi terjemahan. Jakarta. Kencana.

Setiadi. (2007). Anatomi dan Fisiologi Manusia, Edisi Pertama. Yogyakarta: Graha Ilmu.

Slavin, R. E. (2011). Educational Physicology Theory and Practice. United Statet of America: Pearson

Slavin, R. E. 2006. Educational Physicology Theory and Practice $8^{\text {th }}$ Edition. United Statet of America: Pearson.

Sugiarto, I. (2004). Mengoptimalkan Daya Kerja Otak Dengan Berpikir Holistik \& Kreatif. Jakarta: Gramedia Utama.

Sugiyono. (2014). Metode Penelitian Kombinasi (Mixed methods). Bandung: Alfabeta.

Syah, Muhhibin. 2010. Psikologi pendidikan dengan pendekatan Baru. Bandung: PT Remaja Rosdakarya.

Swarabama, I.G. et al. 2013. Pengaruh Model Pembelajaran Sains Teknologi Masyarakat Terhadap Pemahaman Konsep Biologi dan Keterampilan Berpikir Kreatif Siswa SMA. Jurnal Program Pascasarjana Undiksa, 3(1): 1-10. [diakses: 14-06-2016]

Thiagarajan \& Semmel. 1974. Instructional Development for Traning Teacher of Exceptional Children a Sourcebook. Indiana: Indiana University 